\title{
バッファーアンプを内蔵した表面電極 \\ EMG Electrode-Unit Mounted on Buffer-Amplifiers
}

\author{
藤澤政紀、川田 毅、松田 葉、石橋寛二、内田憲二* 、山田好秋 ** \\ Masanori Fujisawa, Tsuyoshi Kawada, Yoh Matsuda, Kanji Ishibashi, \\ Kenji Uchida*, Yoshiaki Yamada** \\ 岩手医科大学歯学部歯科補経学第 2 講座 \\ $*$ 長崎大学歯学部 $* *$ 長崎大学歯学部口腔生理学講座 \\ Department of Fixed Prosthodontics,School of Dentistry, Iwate Medical University \\ * School of Dentistry, Nagasaki University \\ * * Department of Oral Physiology,School of Dentistry,Nagasaki University
}

実験室で表面電極により筋電図を記録すると きは、商用電源からの交流雑音を混入させない ために、シールドルーム内で行うことが多い。 歯科診療室のチェアーサイドや患者の自宅で、 簡易型筋電計により筋電図を記録する ${ }^{11}$ 場合に はシールドルームを使用しないので筋電図に交 流雑音が含まれやすい。この雑音を除くために、 ハムフィルターを通して記録すると、筋電図の 主要な成分を記録できないことになる。こういっ た雑音の為害性は、患者が自宅で $\mathrm{E} M \mathrm{M} \mathrm{G}$ バイオ フィードバック装置を使用する場合にも問題と なる。

筋電図分析で問題となる雑音の多くは、電極 と $\mathrm{AC} ン フ ゚$ 間をつなぐワイヤーから混入する。 そこで、表面電極とバッファーアンプを一体化 した電極ユニットを考案した。そして、この電 極ユニットでとらえた筋電図波形に雑音が混入 しにくいことを確認した。

\section{I 、試作した表面電極ユニット}

今回試作した電極ユニットは、Yamagaら 2$)$ が考案した電極ユニット(以下”バッファーアン プなしの電極”とする)をべースとした。試作し た電極ユニットは、2個の $\mathrm{Ag}-\mathrm{AgCl}$ 血状表面電 極を電極中心間距離 $20 \mathrm{~mm}$ でプラスチックシー トの片面に固定し、電極間に両面接着テープを つけ裏面に小型のICチップ(NJM 064;新日本無 線)を備えつけたもの(以下”バッファーアンプ 付きの電極”とする)である。

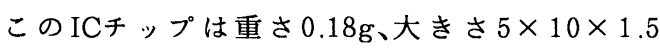

$\mathrm{mm}$ 軽量小型である。ICチップの中には4個 のOPアンプが組み込まれている。OPアンプは 入カインピーダンス $10^{14} \Omega$ 、出カインピーダン ス $10 \Omega$ 以下、と筋電計に要求される性能 ${ }^{3)}$ を満 足している。4個のOPアンプのうち、2個は表 面電極でとらえた信号のバッファ一用に、1個 は不関電極のバッファ一用にそれぞれの表面電

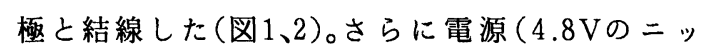
カド電池)用のワイヤー2本を加え、計 5 本のワ イヤーを結線した。ワイヤーには直径 $0.5 \mathrm{~mm}$ の 銅線ワイヤーを用いた。電極ユニットを小型単 純化するために、バッファーアンプの利得を 1 とした。すなわち、バッファーアンプはインピー ダンス変換器として作用する。結線したバッファー アンプをプラスチックシートに接着剤で固定し、 防水のために、結線したワイヤーの一部を含め て、エポキシ系の接着剤で覆った。

\section{II . 実験方法}

歯科外来のチェアーサイドや患者の自宅など で筋電図を記録するときに混入しうる雑音を想 定し、シールド設備のない部屋で、いくつかの 電化製品を周囲で作動させながら実験した。

\section{<実験 $1>$}

バッファーアンプなしの電極およびバッファー アンプ付きの電極を交互に使用してガム咀嚼時 の筋電図を導出した。どちらの電極も右側咬筋 上の皮鹿の同じ部位に貼付した。 


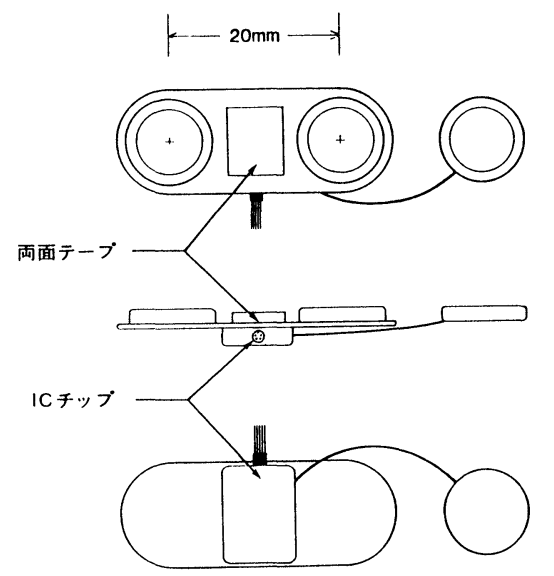

困1試作した電極ユニット

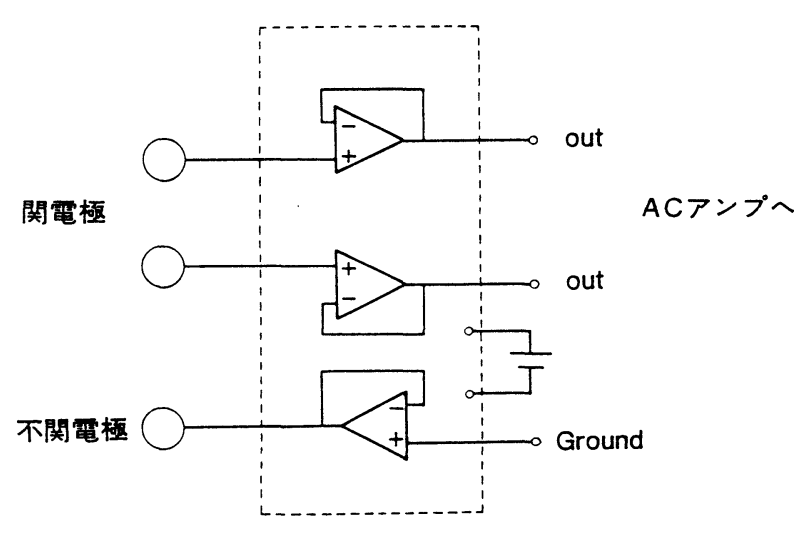

図2 バッファーアンプ結線図

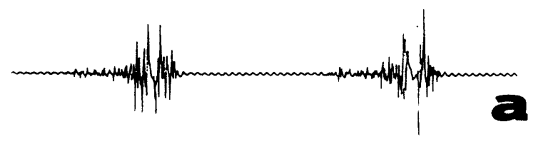

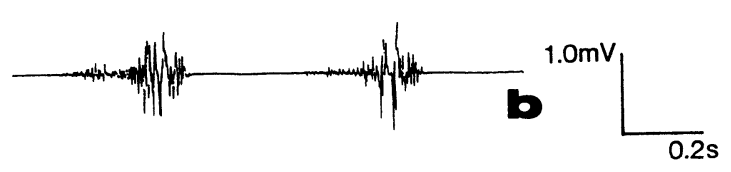

図3ワイヤーに手を触れないときの筋電図 $\mathrm{a}:$ バッファーアンプなしの電極使用 $\mathrm{b}:$ バッファーアンプ付きの電極使用
図4 ワイヤーに手を触れたときの筋電図 a:バッファーアンプなしの電極使用

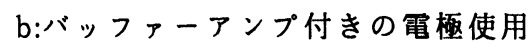

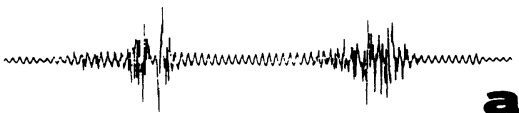
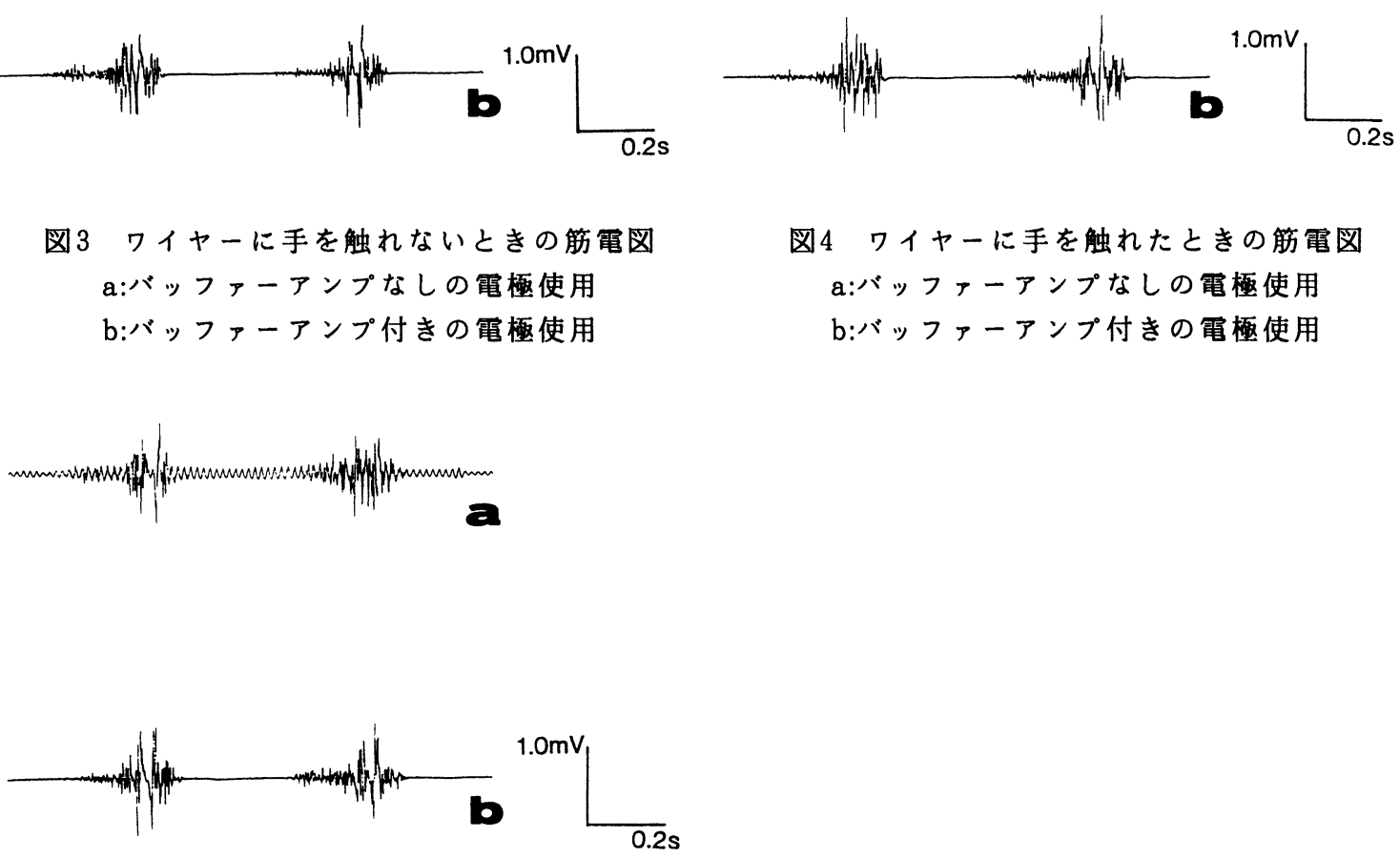

図5 ワイヤーを手で摇らしたときの筋電図 $\mathrm{a}:$ ハッファーアンプなしの電極使用

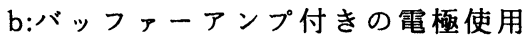


導出時、以下のように条件を変えて記録した。 1)記録中、電極と $\mathrm{AC}$ アンプ間のワイヤーに触 れない(すなわち通常の記録方法)。

2)記録中、ワイヤーに手を触れる。

3)記録中、ワイヤーを手で摇らす。

導出した筋電図をFMデータレコーダ（A-69: SONY)にテープスピード $19 \mathrm{~cm} / \mathrm{s} て ゙$ 記録し $1.9 \mathrm{~cm}$ /sのテープスピードで再生してペンレコーダに より記録紙に波形を表示した。

\section{<実験 2>}

バッファーアンプを介することで、波形の周 波数成分が影響を受けるかどうかを調べるため に、両方の電極を用いて記録した咬みしめ時の 筋電図周波数成分を比較した。

同一被験者の右側咬筋の同一部位に、バッファー アンプ付きの電極と、バッファーアンプなしの 電極を交互に貼付し、最大咬みしめを持続させ た。咬みしめ初期の $5 \mathrm{~s}$ 筋電図パワースペクト ルを、FFTアルゴリズムにより求めた。筋電図 を $\mathrm{A} / \mathrm{D}$ 変換する際のサンプリング間隔を $0.5 \mathrm{~ms}$ 、 1区間のサンプリングポイントを1024点として、 連続する10区間すなわち5.12sのパワーを加算 した。こうして求めたパワースペクトルの3.9$1000 \mathrm{~Hz}$ の総パワー値を $100 \%$ とし累積 $20 、 50 、 80$ \%值および mean power frequencyを求めた 4$)$ 。 これらの值をシグナルプロセッサ7T-18(日本電 気三栄)で計算した。なお、疲労の影辢を受け ないように咬みしめと咬みしめの間には充分な 休息をもうけた。

\section{III. 結果}

\section{1、ガム咀覆時の筋電図から}

1)電極とACアンプの間のワイヤーに手を触 れずに記録した場合

バッファーアンプなしの電極を用いて導出し た筋電図は、筋活動休止期にも振幅が出現(図3a矢印)した。一方、バッファーアンプ付きの電 極を通して記録した筋電図波形にはこのような 雑音は全く含まれていなかった(図3-b)。

2)記録中ワイャーに手を触れた場合

バッファーアンプなしの電極で導出した筋電 図波形には交流雑音が混入したが、バッファー アンプ付きの電極で導出した波形には雑音がな かった(図4-a、b)。

3)記録中にワイヤーを手で摇らした場合 バッファーアンプ付きの電極で導出した波形 は何ら影響を受けていないが、バッファーアン プなしの電極での記録には交流雑音のほかにも 雑音が含まれている。この雑音はワイヤーを摇 らした周期に一致していた（図5)。

2、咬みしめ時の筋電図から

累積 $20 、 50 、 80 \%$ 値及び mean power frequency はどちらの電極で導出した場合もほぼ同じ值で あった。

IV. 考察

外来のチェアーサイドや患者の日常生活の場 で筋電図を記録することは、より多くの有益な 情報が得られる利点がある。しかし、雑音対策 設備がないので筋電図に交流雑音が混入しやす くなり、この雑音が分析の妨げとなる。加えて、 頭位を変えるなどして電極と $\mathrm{AC}$ アンプ間のワ イヤーが摇れると、その振動に一致した雑音が 混入する。この現象は地面とワイヤ一間の浮遊 容量が原因で生じるものでモーションアーチファ クトとよばれている ${ }^{3)}$ 。困3-aの振幅は、開口運 動のためにワイヤーが摇れたことが原因で生じ たモーションアーチファクトと思われる。図5aでは交流雑音とモーションアーチファクトの 両方が含まれている。

多くの雑音はワイヤーから混入する。そこで、 こういった雑音から信号を守るために、バッファー アンプを通してインピーダンス変換した。この バッファーアンプは入カインピーダンスが $10^{14}$ $\Omega$ 、出力インピーダンスが $10 \Omega$ 以下であるので バッファーアンプを通過した信号に雑音が混入 しにくくなる。また、信号成分はバッファーア ンプを通過してあ変化しない。

試作した電極ユニットに用いたOPアンプは、 軽量小型で容易に組み込むことができしかも安 価である。加えて取り扱いむ容易で、患者自身 で電極の貼付、清掃ができる。 


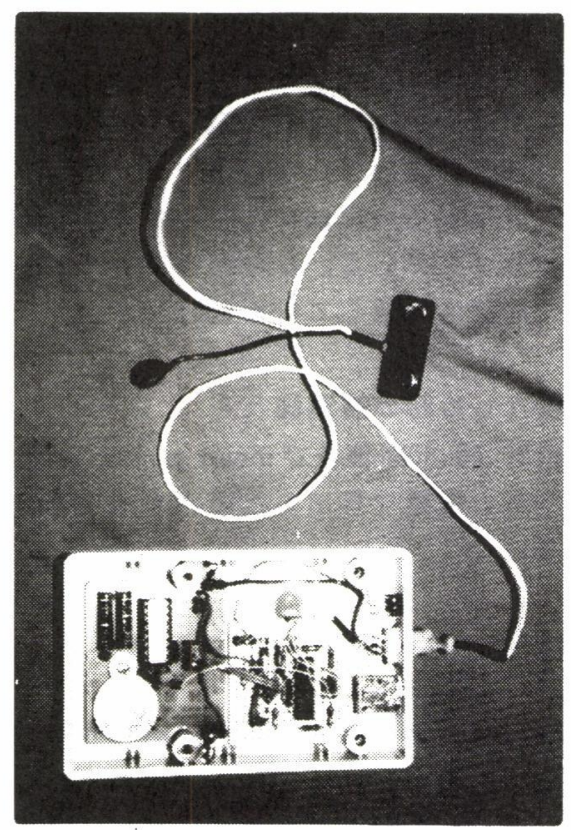

図6 ポータブル筋電計への応用

本電極ユニットの臨床応用として、ポータブ ル筋電計との組み合わせが考えられる。チェアー サイドや患者の自宅で筋電図を記録することで 診査、診断に有益な情報を得ることができる。 さらには簡易バイオフィードバック装置に組み 込むことで筋弛緩訓練などの治療に役立つ。

図 6 は電極ユニットをポータブル筋電計と組み 合わせたあのであり、図 7 は患者がポータブル 筋電計を使用しているところである。

試作した電極ユニットは、電極間距離を常に 一定に保つ、両面接着テープで被験筋上の皮虑

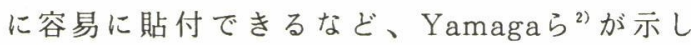
た電極の長所も備えている。

\section{V.まとめ}

チェアーサイド、あるいは患者の自宅で筋電 図を記録することを前提として、筋電図に混入 する雑音を防ぐ電極ユニットを試作した。本電 極ユニットは筋電図記録に必要な要件を満たし ており、記録した筋電図には交流電源、モーショ ンアーチファクトなどの雑音が含まれない。 本電極ユニットとポータブル筋電計を組み合

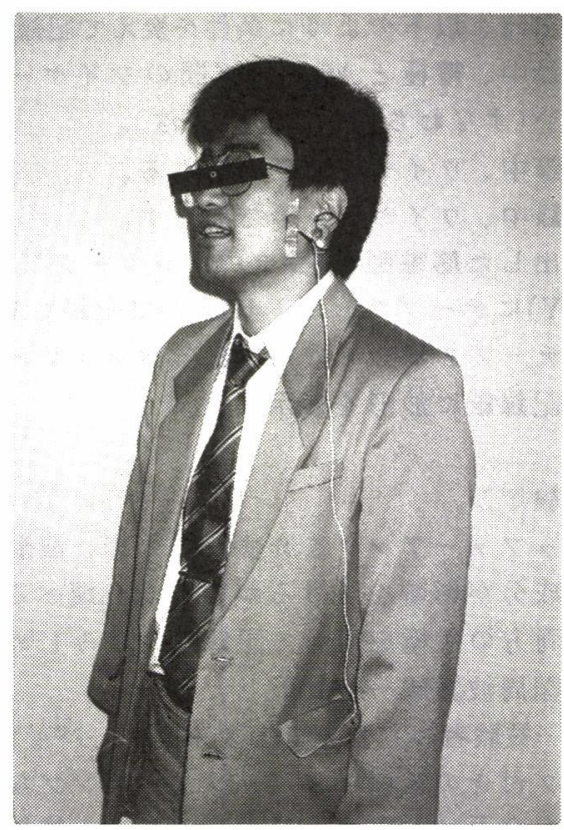

図7 ポータブル筋電計による筋電図記録風景

わせることにより、筋電図検査やバイオフィー ドバック装置の臨床応用がさらに発展するもの と思われる。

\section{参考文献}

1) Solberg W.K., Clark G.T., Rugh J.D.:

Nocturnal electromyographic evaluation of bruxism patients undergoing short term splint therapy. J Oral Rehabil,2:215-213,1975

2) Yamaga $T$, Yamada $Y$, Ishioka $K$ :SingleUnit surface electrode pair for use in electromyography. J Prosthet Dent,48:624,1982

3) Basmajian J.V. and De Luca C.J.:Muscles Alive,19-64,Williams \& Wilkins,1985 4)藤澤政紀:Tapping、ガム咀嚼、および咬みしめ 時における咀嚼筋 E M G のPower spectrum解 析補綴誌, $32: 1-10,1988$ 